\title{
Impact of Locus of Control Expectancy on Level of Well-Being
}

\author{
Kurt A. April (Corresponding author) \\ Ashridge Business School, University of Cape Town \\ Private Bag X3, Rondebosch, 7701 Berkhamsted, HP4 1NS Cape Town, South Africa \\ Tel: 27-21-406-1411Ｅ-mail: kurt.april@gsb.uct.ac.za \\ Babar Dharani \\ Ashridge Business School, University of Cape Town \\ Private Bag X3, Rondebosch, 7701 Berkhamsted, HP4 1NS Cape Town, South Africa \\ E-mail: babardharani@gmail.com
}

Kai Peters

Ashridge Business School

Berkhamsted, Hertfordshire, HP4 1NS, United Kingdom

E-mail: kai.peters@ashridge.org.uk

Received: March 19, 2012

Accepted: April 23, $2012 \quad$ Published: June 1, 2012

doi:10.5539/res.v4n2p124

URL: http://dx.doi.org/10.5539/res.v4n2p124

\begin{abstract}
This paper investigates the impact of locus of control, a psychological social learning theory that is rigorously researched for its implications on leadership qualities, on the level of happiness of an individual. The primary research strategy employed was the survey strategy. Participants were asked to fill in a questionnaire that was designed to test, amongst other variables, their locus of control and level of happiness. The Spearman Rank Correlation hypothesis test was used to test the data for significance and strength of the relationship. As a secondary research approach, self-reflection documents written by research participants, on the topic of locus of control, were used to add personal expression to the discussion of the quantitative results. While academic literature vastly supports the view that leadership qualities are predominantly present in those with an internal locus of control, our research results conclude that a maximum level of happiness is achieved by individuals with a balanced locus of control expectancy - a mix of internal and external locus of control, alternatively known as 'bi-local expectancy'.
\end{abstract}

Keywords: Locus of control, Subjective well-being, Expectancies, Happiness, Leadership, Bi-Local

\section{Introduction}

Locus of Control is a psychological, social learning theory that refers to the extent to which individuals perceive control over their lives, and environment (Lefcourt, 1976). Hiers and Heckel (1977), Anderson and Schneier (1978), and McCullough, Ashbridge and Pegg (1994) all reported that successful leaders are endowed with a high internal locus of control; whereas, less successful ones typically have a low internal locus of control. The link between internality and leadership may be explained by the fact that individuals with an internal locus of control have faith in their ability to achieve self-appointed objectives (Klein \& Wasserstein-Warnet, 1999) and in transforming their environment (Andrisani \& Nestel, 1976; Klein \& Wasserstein-Warnet, 1999). They feel personally responsible for the job's success, and when something backfires, it is attributed to inadequate participation on their part (Klein \& Wasserstein-Warnet, 1999).

While internality is vastly regarded as a trait of leaders, how does it relate to the level of happiness of a leader? Academic literature provides some indication of the link between well-being and locus of control. An external 
locus of control expectancy is known to have a positive correlation with higher levels of psychological distress (Holder \& Levi, 1988), vulnerability to depression (Ganellen \& Blaney, 1984), and poorer responsiveness to anti-depressants (Reynaert, Janne, Vause, Zdanowicz \& Lejeune, 1995). Furthermore, studies show that locus of control in cultures that foster a high perception of external control also fostered higher rates of suicide (Marks, 1998). On the contrary, there is research evidence that internals tend to be happier in their jobs, are absent less frequently, are less alienated from the work-setting, and tend to be more involved in their jobs compared to externals (Carrim, Basson \& Coetzee, 2006).

While the above implies that externality is associated with lower levels of happiness, does this entail that internality, a known trait of leaders, is associated with higher levels of happiness? In other words, are our leaders happy since they are endowed with highly internal loci of control? The research effectively tries to answer this question.

\section{Literature Review}

\subsection{Locus of control}

The construct 'locus of control' was developed by Julian Rotter in 1966 (Carrim et al., 2006). Rotter (1966) used the empirical law of effect which states that people are inherently motivated to seek positive stimulation, or reinforcement, and avoid unpleasant stimulation. Rotter (1966) used Skinner's (1974) concept of reinforcement which stated that if the outcomes of responses by an individual are favourable or unfavourable, then the likelihood of the operant to use the response in the future is increased or decreased respectively - this is positive and negative reinforcement. Reinforcement, experienced by an individual, acts directly to strengthen anticipation that a particular behaviour, or event, will be followed by similar reinforcement in the future (Rotter, 1966). This anticipation of reinforcement is regarded as expectancy. With development of this expectancy, individuals learn to discriminate behaviours and outcomes, and generalise these anticipations for the future. This generalisation of expectancies of control of reinforcements defines and formulates one's locus of control (Rotter, Seeman \& Liverant, 1962). On this basis, Lefcourt (1976) generated a predictive formula where he defined behaviour potential (the likelihood of engaging in a particular behaviour) as a function of expectancy (the probability that a given behaviour will lead to a particular outcome) and reinforcements (outcomes of our behaviour).

A belief of individuals about controllability over what happens to them in life is a core element of their understanding of how they live in the world (Shapiro, Schwartz \& Austin, 1996). Locus of control is a personality construct that reflects one's belief or perception about who controls life and the environment (Lefcourt, 1976). The belief can exist in varying levels, reflecting the degree to which one perceives personal control in life and over the environment (Connolly, 1980). Locus of control has been described as a dimension with two opposing differentiates (Lee-Kelley, 2006). The dimensions reflect the extent to which individuals believe that what happens to them is within their control, or beyond it (Carrim et al., 2006). This presents a continuum of an internal-external belief system (Littunen \& Storhammar, 2000), as shown in Figure 1.

People with an internal locus of control believe that the outcomes of their actions are a result of their own personal efforts (Andrisani \& Nestel, 1976), abilities (Carrim et al., 2006), or permanent characteristics (Littunen \& Storhammar, 2000). They believe that hard work and personal abilities lead to positive outcomes (Carrim et al., 2006). Thus, these individuals interpret reinforcements they receive from their surroundings as contingent upon their own actions (Lee-Kelley, 2006). For internals, key links exist between behaviour and consequences, and between outcome and personal effort (Connolly, 1980). This belief entails that they are masters of their fates (Boone, van Olffen \& van Witteloostuijn, 2005).

On the contrary, people with an external locus of control believe that their own actions are dependent on factors outside their personal control (Landy \& Contre, 2004; Martin, Thomas, Charles, Epitropaki \& McNamara, 2005). The consequences of behaviour are randomly administered, and are thought to be controlled by outside forces (Connolly, 1980). Rotter himself had suggested four types of beliefs in externals, which include: powerful others, luck or chance, fate, and a belief that the world is too complex to be predicted (Marks, 1998). Popularly, external locus of control has separated external control into: control by powerful others, and control by chance and luck (Levenson, 1973; Levenson \& Miller, 1976). Externals are reluctant to change behaviour as they do not see it as a primary source for altering reinforcements (Marks, 1998). Even in the case of positive reinforcement, the credit may not be taken personally, but reflected upon ease of task, luck or on a helpful hand by a powerful other (Hyatt \& Prawitt, 2001).

The generalised expectancies of the perception of control are a collaboration of specific expectancies that vary from one life function to another (April \& Smit, 2010). In addition to the internal and external locus of control expectancy, the concept of dual control entails a mix of internality and externality within an individual (Torun \& 
April, 2006). How these expectancies coexist is not completely understood (Connolly, 1980), but it can be expected that a combination of internal and external expectancies in different specific situations of an individual can lead to a generalised expectancy that is bi-local. Wong and Sproule (1984) state "bi-locals cope more efficiently by having a mix of internal control (personal responsibility) and external control (faith in outside resources)" (p.320). However, this view is not predominant in academic literature, where the majority of the authors' present a preference towards internality for individual accomplishments and leadership.

\subsection{Rotter's internal external scale}

Rotter's (1966) internal-external scale tests locus of control expectancy using 29 questions (Figure 2). Each question has two options for the participant to choose from: one option expresses a typical attitude of internal locus of control expectancy, and the other indicative of the attitude of external expectancy. This choice represents an extreme option, and the participants are asked to choose the option which they more strongly believe in (Lefcourt, 1976), or the option that is closest to their preference (Klein \& Wasserstein-Warnet, 1999). One point is scored for each external option chosen by the participant; thus, the higher the score, the more external the individual is regarded.

In analysing Rotter's (1966) internal-external scale, Tyler, Gatz and Keenan (1979) concluded in support of the view that locus of control is a personality characteristic which is, in part, actively organised by the individual and not passively accrued. As such, this construct can be positively studied and accrued accordingly using the scale.

In social learning theory (Bandura 1994, 1977, 1973), two kinds of expectancies are distinguished: situation-specific and generalised expectancies. Situation-specific expectancies are determined, to a large extent, by the experience of individuals in that specific situation (Lefcourt, 1976). Also, individuals develop relatively stable expectancies, which are the result of generalising life-time experience. Numerous studies have shown that Rotter's (1966) scale is multi-dimensional in nature (Boone \& De Brabander, 1997). This has led to development of several measures of situation-specific locus of control expectancies, but this does not render multi-dimensional internal-external scale as meaningless (Boone \& De Brabander, 1997). Ashkanasy (1985) concludes that "from an operational point of view ... it appears that Rotter's scale, despite an overhead of irrelevant items, measures the useful and essential unitary personality variable" (p.1338). Boone and De Brabander (1997) concluded that although Rotter's IE scale contains measurements of error (as many scales do), it is an adequate measure of generalised control expectancies.

\subsection{Understanding happiness}

The definitions of happiness are wide and varied. The complication regarding happiness arises due to the various different understandings of the term, and confusion between happiness and other positive emotions (Haidt, 2006). To effectively differentiate these positive feelings from the term 'happiness', a few positive emotions are described below:

\subsubsection{Pleasure or euphoria}

Darwin (1936), in explaining the evolution of species, examined natural selection as adaptation of species to their environment to allow particular species to thrive. To reinforce a behaviour that allows for successful survival of the species in an environment, animals get a rush of dopamine (the pleasure hormone) when any actions are taken by the animal which allows for the advancement of the evolutionary interest of the species; for example, while mating, or eating. This reinforcement allows for positive feelings to be experienced by the animal, classified as pleasure (Ricard, 2006) to effectively encourage such behaviour in the animal which allows for survival of the species.

Similarly, in humans, this dopamine reinforcement is primarily experienced during sex and while eating. In addition, dopamine release is recorded during most entertainment activities such as: scalp massage, intense workout, listening to drums, acupuncture, and intense sunlight to name a few (McPeck, 2007). The reinforcement by dopamine comes seconds after the action is taken. This provides a feeling of euphoria, or pleasure. Unfortunately, this positive feeling is not long lasting. Such exciting positive emotions last for hours or, at best, a day or two (Haidt, 2006; Ricard, 2006).

In addition to dopamine, in the context of successfully achieving a goal over time, endorphins are released which increases desire and motivation towards the reward. This desire and motivation, due to the influence of endorphins, allows for enhanced release of dopamine; thus, allowing for an experience of intense pleasure, which can be described as exhilaration or ecstasy (Haidt, 2006). This confirms the saying that delayed gratification allows for more pleasure (Carney, 2007). Similarly to pleasure, the positive emotions experienced by an endorphin rush and subsequent release of dopamine do not last long. 


\subsubsection{Joy and happiness}

Lyubomirsky, Sheldon and Schkade (2005) constructed the happiness formula which regards genetic dispositions, environmental factors and voluntary activities as determining the level of happiness of an individual. A biological set point predominantly determines one's level of happiness, while circumstantial influences account for up to only $15 \%$ contribution (Ricard, 2006).

On the contrary, Haidt (2006) defines success as advancement in evolutionary interest which is described as pleasure and euphoria, or even ecstasy. The post-goal-attainment positive affect (Davidson, 1998) is of contentment, and short-lived euphoria discussed above; however, the pre-goal attainment positive effect experienced by an individual, as little progresses are made throughout the journey to the goal, is defined as the "progress principle". Haidt (2006) defines happiness as the "progress principle" (p.82). This reaffirms the saying that it is the journey that counts, not the destination (Timmons, Spinelli \& Zacharakis, 2005).

While the above presents a scientific view of happiness, different cultural, social and religious beliefs define happiness differently from each other, and differently from the scientific view above. Joy is differentiated from happiness in the Buddhist belief which claims that joy, unlike happiness, can be obtained with respect to harm to others (Ricard, 2006; Bstan-Dzin-Rgya-Mtsho \& Cutler, 1998). The presence of joy in the absence of malice is what allows for happiness to thrive (Bstan-Dzin-Rgya-Mtsho \& Cutler, 1998). The Dali Lama profoundly states that a pure and healthy mind does not allow for thoughts of malice (Bstan-Dzin-Rgya-Mtsho \& Cutler, 1998), let alone actions of a malicious nature. Thus, happiness is held to be a deep sense of flourishing that arises from an exceptionally healthy mind (Ricard, 2006).

The concept of lack of malice and the importance of society for a healthy mind that leads to personal happiness of an individual is not limited to the Buddhist belief. Adler (1956) concludes that every individual has natural aptitude for community feeling, or social interest. He explains this as an innate ability to engage in corporative, reciprocal social relations. Individual psychology assumes an essential corporative harmony between individual and society, and regards conflicts as an unnatural condition. According to Adler (1956), the degree of social interest is a good measure of the individual's psychological health, and a healthy mind is regarded as happy (Ricard, 2006).

Hawa (2004) asserts that Islamic spirituality is capable of producing a complete Muslim, who would worship Allah and also be a valuable member to society through kindness. Ali (2005) also captured that spiritual and mental needs strengthen the quest for perfection and actualization of one's potential in serving the community and organisation, while pursuing his/her activities. According to Ali (2005), "spiritual people enjoy minds that are motivated towards good deeds and complete satisfaction and self-actualization" (p. 28). The above posits an assumption relating to 'action' and 'individual orientation' as a path to happiness. Kamil, Al-Kahtani and Sulaiman (2011) go even further in their assertion with respect to 'obligations' and 'correct behaviour', which hints at happiness linked to 'connectivity' or responsibility to fellow humans, nature and other creations.

The catholic faith defines pleasures as positive feelings that can be achieved by "world structures" (Benedict XVI, 2007, p.36); however, it emphasises that these cannot bring well-being; thus, differentiating pleasure and euphoria from joy and happiness. Joy is defined as a lack of suffering. While the catholic faith recognises the importance of limiting suffering for oneself and for others, and recognises the need to fighting against it, the faith also recognises that while "we can limit suffering ... we cannot eliminate it" (Benedict XVI, 2007, p.48). It is the capacity for accepting suffering, maturing through it that allows for happiness.

\subsubsection{Subjective well-being}

As described above, the variety of world beliefs and cultures entail that a unanimous definition of happiness is difficult to achieve; however, the concept of well-being for an individual lies at the core of the varied definitions of happiness and allows for a means for measuring the level of happiness. Subjective well-being focuses on understanding the complete range of well-being: from utter despair to elation and total life satisfaction. Good and bad events cause a positive or negative deflection from the baseline; however, it appears that over time, the person drifts back to their baseline (Suh, Diener, Oishi \& Triandis, 1998). This entails that subjective well-being does not measure temporary feelings of euphoria, pleasure, ecstasy or exhilaration, but measures long-term positive feelings of joy or happiness of individuals.

The structure of subjective well-being has been conceptualized as consisting of two major components: the emotional or affective component, and the judgmental or cognitive component (Diener, 1984; Veenhoven, 1991). The judgmental component has also been conceptualized as life satisfaction (Andrews \& Withey, 1976). In the 
cognitive form, subjective well-being is an evaluation of a person's judgement about his or her satisfaction with life as a whole.

Pleasant and unpleasant effects, which determine subjective well-being, have a degree of constancy and stability over a period of many years. This ensures that the concept allows for conclusive evidence of the level of joy or happiness of the research participants (Costa \& McCrae, 1988; Headey \& Wearing, 1992),

\section{Methodology}

\subsection{Primary approach: questionnaire}

Andrisani and Nestel (1976) list the non-personality variables that influence the level of responsibility that is held by an individual in their profession. Their study ranked education as a highly influential variable. Thus, to potentially target the population that either has attained, or is likely to attain leadership roles in society, the sampling methodology targeted individuals that are currently studying at the Graduate School of Business of the University of Cape Town (South Africa), and the alumni of the Business School.

The researchers used an on-line, self-administered questionnaire (Saunders, Lewis \& Thornhill, 2003) which was completed by the respondents, and the results were compiled electronically. The choice of the type of questionnaire employed was driven by several considerations, prominent among which were: cost, time, and assurance that the responses were from the intended respondents.

\subsection{Measuring locus of control expectancy}

The questionnaire included the abbreviated version of the internal-external scale questionnaire (Rotter, 1966) that tested the locus of control of the participants. Klockars and Varnum (1975) examined the polarity of the two choices for the questions in Rotter's (1966) internal-external scale to conclude validity for 11 out of the 23 questions as directly opposing options for the questions. Furthermore, Adeyemi-Bello's (2001) study concluded that 23 items were too many to measure one construct. It is potentially for the above reasons that Andrisani and Nestel (1976) used an 11 item abbreviated version of Rotter's (1966) internal-external control scale for their research. In light of this assessment by previous researchers, the 11 item abbreviated scale was used for measuring locus of control expectancy of the participants.

Instead of a forced choice, Andrisani and Nestel (1976) allowed the respondents to score each statement from one to four, based on the level of conviction towards the statement. Similarly, Joe and Jahn (1973) extended the version of the forced choice format in which the subjects had to indicate intensity of their choice on a six point scale. Klockars and Varnum (1975) tested the scale and concluded the above to be more coherent than two widely separated points. This was further reflected by Adeyemi-Bello's (2001) study, where the two choices given in Rotter's (1966) internal-external scale were viewed as two extremes which polarised participants, but agreed with both the statements of internality and externality to a very similar extent. Nonetheless, Rotter's (1966) research on locus of control has 'matured' and though Rotter's (1966) original internal-external scale has had a share of alternative scales (including scales from Chung \& Ding, 2002, Gupchup \& Wolfgang, 1997 and Spector, 1988, to name a few), the logic of Rotter's (1966) scale and structure of using two forced choice format continues to be in use (Lee-Kelley, 2006). It was on this basis that the restricted choice version of Rotter's questionnaire was retained for this research.

\subsection{Measuring happiness}

The usual method of measuring subjective well-being is through self-reported surveys in which participants judge and report their life satisfaction. While several sets of questionnaires are available to measure subjective well-being, Sandvik, Diener and Seidlitz (1993) report that various self-report scales measuring subjective well-being usually correlate well with each other, which reflect on unanimity of the concept of subjective well-being. Diener, Emmons, Larsen and Griffin (1985) created a five question survey, named 'satisfaction with life scale', which was developed as a measure of the judgmental component of subjective well-being. This scale measuring subjective well-being has adequate validity, according to Pavot and Diener (1993).

The field of subjective well-being ranges from agony to ecstasy, from thorough satisfaction with life to depression and hopelessness. However, more relevantly for the purposes of this research, the scale can differentiate between slightly happy people to extremely happy people (Diener et al., 1997). This is achieved via five questions that allow a range of responses, from strongly agreeing to strongly disagreeing to the statement. The same method and scale for measuring satisfaction with life was used for the research. 


\subsection{Secondary approach: personal reflections of research participants}

The research undertook a through analysis of the documents written by the research participants on their personal reflections regarding their locus of control expectancies. The analysis was conducted using specialist qualitative analysis software, AtlasTI, predominantly by the use of auto-coding to avoid bias. This analysis was used to further validate the survey results and increase the richness of the paper (Saunders et al., 2003).

Permission from 38 full-time MBA students and 25 modular MBA students were obtained. Thus, a total of 63 personal reflections were analysed for the research. These insights were documented after review of the concept of locus of control by the participants. This review was used by the researchers to ensure a thorough understanding of the concept by the participants in order to add to the reliability and validity of the research conducted, as an understanding of the concept allows for better self-reflection in respect of the concept. These reflections were used in the research to identify the common 'stumbling blocks' to well-being for internals. This analysis allowed for exploration of potential 'enablers' to devise strategies for changing one's locus of control expectancy as deemed appropriate (Cummings \& Wilson, 2003).

\subsection{Data analysis}

Correlation study examines the extent to which differences in one characteristic or variable is related to differences in one or more other characteristics or variables (Leedy \& Ormrod, 2005). A correlation is a statistic that measures the strength and direction of a linear relationship between two variables (Utts \& Heckard, 2007). Both the variables, locus of control and subjective well-being, were expected not to be normally distributed (Utts \& Heckard, 2007), as subjective well-being results are known to be positively skewed (Suh et al., 1998) and to be ordinal (Utts \& Heckard, 2007), as scores of only round numbers can be achieved by the participants. For data that is not normally distributed, and is ordinal, Spearman Rank Order Correlation is an appropriate hypothesis test to be used for finding correlation for the data.

\section{Findings}

A total of 140 responses were received to the questionnaire; however, the results were based on a sample of 114 responses. 26 responses were eliminated from the sample for testing on the basis that all the mandatory questions were not completed by these respondents. The sample included an international body of alumni of the Graduate School of Business $(n=68)$, and current MBA students $(n=46)$, including South Africans and international students. The entire sample $(\mathrm{n}=114)$ was used for regression analysis for locus of control and subjective well-being.

In light of the sampling methodology, the study did not presume to be representative for the world population in general. The sample potentially represented a sub-group of the population that was more academic and educated. The need for higher education for obtaining management roles in the commercial world is evident and documented (Knowles, Holton, \& Swanson, 1998; Grobler, Warnich, Carrell, Elbert \& Hatfield, 2006; Van Dyk, Nel, Van Zloedoff \& Haasbroek, 2001; Wilson, 1999). Thus, it was hoped that the population captured by the questionnaire had greater potential for securing high-level management positions, and included people either currently in a management role, or those with the potential for management roles.

For testing the relationship between locus of control and subjective well-being, the respondents were divided into two. None of the respondents had a locus of control expectancy result of 11, therefore, scores of 0 to 5 were classified as participants with an internal locus of control expectancy and those with scores of 5 to 10 were classified as externals. The results are graphically represented in Figure 3.

Both tests reveal a $1 \%$ level of statistical significance (Table 1), which provides proof of a positive relationship between decreasing internality and subjective well-being, and a stronger negative relationship between increasing externality and subjective well-being.

\section{Discussion}

The results significantly conclude that the maximum level of happiness is achieved by individuals with a bi-local expectancy (Figure 4). The researchers feel that in respect of internal, external and bi-local expectancies, the middle-road that allows for maximum level of well-being represents not a polarisation of both the expectancies, as the term 'bi-local' suggests, but represents a balanced locus of control expectancy of an individual, while internal and external expectancies both represent extremes and are representative of an imbalanced locus of control expectancy. This emphasises the common concept of the importance of balance in life, and a perception that extremities should be avoided for optimal well-being. 
The lack of well-being for extreme externals is well documented in academic literature and is linked to depression, powerlessness (Marks, 1998; Torun \& April, 2006), helplessness and also learned helplessness (Connolly, 1980; Peterson, Maier \& Seligman, 1993; Hiroto, 1974; Cohen, Rothbart \& Phills, 1976), and hopelessness (Minkoff, Bergman, Beck \& Beck, 1973; Kobler \& Scotland, 1964) in pathological cases.

The lack of satisfaction and happiness attributed directly to an external locus of control expectancy was clearly stated by the research participants in their personal reflections. For example, in reference to externality where control is perceived to be in the hands of powerful others, one research participant explained: "I am consistently externally affected by 'powerful others'... my Dad and other influential people has often led to me feeling inadequate. Even if I know that I have performed brilliantly, I often do not get any satisfaction..." (46:2). This attributes a lack of satisfaction and feeling of inadequacy for the participant with an external locus of control expectancy because credit for the performance is not attributed to oneself, but to external forces. The participant added: "... external locus of control, of powerful others affecting me, was so entrenched in me that I even became dissatisfied in my job" (46:7).

Similarly, an extreme case of unawareness of external forces, to which reinforcement is attributed, led one of the research participants to possess a very low level of subjective well-being. This research participant expresses the discovery of: “... a new dimension to the 'powerful others' in my life, these have been termed 'they they'... 'They They' are voices in my head that plague me ... and .... I fell into deep depression and only found release in self mutilation. Over the years these voices strengthened ... until eventually it got too much and I ... had a nervous breakdown" (18:19). This potentially expresses the pathological level of externality, where 'powerful others' led the participant to feel helpless and powerless.

On the contrary to academic evidence of externality and lower levels of well-being, lower levels of well-being experienced by extreme internals is not well documented in academic literature. In the analysis of locus of control self-reflection documents, an overwhelming support for a lack of well-being for internals is made available and is discussed below.

\subsection{Stress caused by assuming too much responsibility}

The analysis entails that internals, by attributing responsibility of outcomes to their own actions, rather than attributing responsibility to environmental or other external factors, perceive a very high level of responsibility, which often leads to stress. This is explained by one research participant as: "My biggest stumbling block [for having an] internal locus of control is stress. My awareness of being responsible and accountable for myself generates stress" (14:3). Similarly, with regard to excess responsibility, another research participant stated: "I take responsibility and feel accountable in situations beyond my control, and should sometimes be more kind towards myself and less self punitive" (21:4). This high level of responsibility for all happenings in one's life is regarded by one research participant as: "Unrealistic expectation of what outcomes can realistically be influenced" (11:10), which can lead to "... potential for distress and emotional breakdowns as a result of assuming too much responsibility” (25:7).

\subsection{Feelings of guilt in case of non-achievement and high level of self-criticism}

Furthermore, taking on too much responsibility for one's self and the environment can cause one to be very critical of oneself and accountable for every outcome. This causes the individual to feel guilty for not sufficiently influencing the outcomes. This is expressed by one of the research participants as: "A feeling of guilt might sometimes come with it, causing sleepless nights and stress" (25:8). One research participant confirms that as an internal: "... you can be too hard on yourself ... always anticipating the future, and needing to succeed in that future" (26:4). Yet another research participant states: "I am rather critical with myself, which correlates with my tendency of performing internally" (22:7).

\subsection{Anxiety experienced due to lack of scapegoats}

While blaming others can be a stumbling block for externals, not having any external factors to blame can cause an inability to present oneself with any external escape route or defences (Kelly, 1955) in times of anxiety. Bovey and Hede (2001) describe defence mechanisms as several types of reactions that protect an individual from overwhelming anxiety. Defence mechanisms are creative adaptations for a psyche to manage anxiety to allow for survival of the individual. Elimination of any external scapegoats, by having a strong belief that control lies within oneself, does not allow extreme internals to shift blame to any alternative source as a possible defence. In the absence of other defences, the individual may either live in anxiety when faced with threats (Kelly, 1955), or may need to cross an edge (Mindell, 2007). Either of the two options is stressful for an individual, and can subject the individual to lower levels of well-being. 
With respect to lack of scapegoats, one research participant explained: "I am quick to blame myself for my lack of achievement" (27:3). Another research participant stated: "Not blaming others for our present circumstances is another stumbling block" (31:2); thus, emphasising the importance of availability of scapegoats for the well-being of an individual's psyche, particularly in the case of internals. While this quality may directly allow for accountability, which is a well-regarded quality for a leader, a very internal locus of control expectancy may pose an unnecessary burden on the leader's psyche in situations which are beyond the control of the individual.

\subsection{Deep fear of loss of control}

It was evident from the analysis of the personal reflections of the research participants that any situation requiring a potential loss of control on the part of the individual, or situations involving ambiguity or uncertainty (Alevesson, 1993), further leads to lower levels of well-being for internals. The low level of well-being, caused by the uncertainties of life, is clearly expressed by one research participant, who stated: "I was not in control myself. To be in that space has caused tremendous stress for me" (9:9). Similarly, another research participant stated: "If I am unable to control a situation, I struggle a great deal to let it go" (33:3). The need for control for well-being, and the absence of it leading to poor well-being, is stated by one research participant as: “... striving to be in control of whichever predicament I find myself in can also act as a stumbling block ... It causes unnecessary stress, owing to the fact that this is not sustainable" (40:2; 40:3). The inability to deal with ambiguity and uncertainty about the future is highlighted by another research participant as: "I very often find that I become anxious about the future ... and cannot control others or things to make the future more predictable" (45:4).

The yearn for control can be so great that one of the research participants stated that, as a child, the participant attempted, in vain, to take control in the case of a house fire. The participant's refusal to relinquish control is expressed by his statement: "I remember starting to throw my mother's pottery bowls into the backyard; the fact that it was all breaking as it landed made little impact on me - I was doing something, refusing to accept that I had lost all control over a situation over which I had no control" (56:4). Similarly, one research participant, while writing about her father's internal locus of control, talks about her father's struggle to keep the family together: "My father... sacrificed, saved, believed and overcame outside influences to achieve the goals he had set for himself. However, once he had got there, the reality of the situation had robbed him of the original purpose of his goal - to provide a better life for his family". The above quotes indicate that an obsession for control can rob one of one's overall goals in life (sometimes in pursuit of a single goal, i.e., work), and that merely striving to fight the odds and ensuring control can come at the expense of one's own dreams and well-being.

One of the research participants stated: "I sat bashing my head against a wall in a situation over which I had no control, yet sat idly by while situations well within my control unfolded in front of me to my detriment ... I think that my obsession with control marred my awareness" (48:1). Thus, the participant highlights the need for self-awareness, and also claimed that there was a need to recognise the difference between what is controllable and what is uncontrollable; thus, adopting a bi-local expectancy, so as to avoid situations where doggedly striving for control leads to stress and lower levels of well-being.

\subsection{Feelings of insecurity due to lack of trust in others and their capabilities}

Another prominent reason for low levels of well-being of individuals with an internal locus of control was attributed by the research participants to a lack of trust in others and their capabilities. In reflection of this, one research participant in the locus of control reflection recited: "Fear of losing control is hindering my trust in others and outside influences" (56:5). Another research participant expressed his or her: "... fear of relying on others so [I] assume responsibility for control and outcomes" (11:12) emphasising the fact that this fear is a trigger for internals to try to take control and, sometimes, could hamper effective teamwork.

This fear can be so immense that a lack of trust can be projected to entire communities and society. One research participant stated: "I find it very difficult to trust people and I don't trust most of the people around me ... unfortunately Apartheid and my upbringing aided in my views of other [lesser] communities" (16:6). In recognition of this stumbling block one research participant expressed the outrage of the research participant's own lack of trust, by stating: "It shocks me how much disbelief in others I have developed" (22:2); thus, recognising this lack of trust as a potential area of stress causation.

\subsection{Loneliness experienced due to lack of compassion}

A lack of compassion in internals can lead to a lack of essential corporative harmony between the individual and society. This conflict is an unnatural condition, according to Adler (1956), and the lower levels of compassion 
are indicative of poor psychological health of the individual. Such a state cannot allow for happiness, according to Ricard (2006).

A trait of internals, observed in the analysis of the locus of control self-reflections, is a lack of compassion. While a research participant with an external locus of control stated: “... kindness of my spiritual guide” (3:7), a research participant with an internal locus of control harshly stated: '... pain is 'weakness leaving the body' and by turning this around, I can say that blaming others is weakness entering the body" (3:6). Such a belief does not allow internals to have any regard for external factors that may possibly be reasons for failure to perform, or underperform, in any task. Similarly, another research participant, when commenting on an episode at a bank where a clerk expressed reasons for failure of performance, stated the following about the clerk's comment: “... 'sometimes these things happen' ... this enraged me even further"' (9:1).

One research participant stated: "I am friendly, yet guarded. I know this is one of my defence mechanisms, strongly related to a sense of connectedness, whereby I consciously keep a distance between myself and others in an attempt to avoid the pain of a potential rejection, or the complication of emotional intimacy" (11:8). This lack of intimacy, "... not giving enough of myself to other people" (18:5) and "... not being transparent" (26:5) have the bearings of inhibiting establishment of relationships and feelings of belonging to a community. Thus, this may bear consequences on the overall levels of well-being.

\section{Conclusion}

The research of locus of control and its impact on the level of subjective well-being concludes a statistically significant relationship between an individual's locus of control expectancy and the level of happiness of an individual.

In reference to externality, academic literature associates high levels of externality with depression, powerlessness (Marks, 1998; Torun \& April, 2006), and helplessness, and also learned helplessness (Connolly, 1980; Peterson et al., 1993, Hiroto, 1974; Cohen et al., 1976), and hopelessness (Minkoff et al., 1973; Kobler \& Scotland, 1964) in pathological cases; thus, associating externality with lower subjective well-being. This is confirmed by our research which concludes a negative correlation between externality and subjective well-being, meaning that higher levels of externality result in lower levels of well-being.

While Rotter (1966) warned against generalising either internality or externality as exclusively attributed to positive or negative qualities, academic literature frequently presents internality as a preferred trait for leadership and a trait that allows for success. Successful leaders are reported to be endowed with a high internal locus of control, whereas less successful ones typically have a low internal locus of control (Hiers \& Heckel, 1977; Anderson \& Schneier, 1978; McCullough et al., 1994). The analysis of self-reflection documents written by the research participants allowed for an understanding of the impact of an internal locus on control on the level of happiness of the individual. The research highlights:

- Stress caused by assuming too much responsibility.

- Anxiety experienced due to lack of scapegoats.

- Feelings of guilt in case of non-achievement of any goal, and high levels of self-criticism.

- Deep fear of loss of control.

- Feelings of insecurity due to lack of trust in others and their capabilities.

- Loneliness experienced due to a lack of compassion in internals, which can lead to a lack of community feeling and belonging.

The above presents reasons for lower levels of happiness for leaders endowed with a highly internal locus of control. Thus, in reference to locus of control, the optimal level of happiness is achieved by a balanced locus of control expectancy, which is a combination of internal and external locus of control expectancy, known also as shared responsibility, dual control or bi-local expectancy (Torun \& April, 2006; Wong \& Sproule, 1984). This highlights the importance of recognising an individual's own ability to influence his/her life and the environment, while having regard for the fact that certain aspects may be uncontrollable by the individual and may be impacted by chance or powerful others (Lefcourt, 1976).

\section{References}

Adeyemi-Bello, T. (2001). Validating Rotter's (1996) locus of control scale with a sample of not-for-profit leaders. Management Research News, 24(6-7), 25-34. http://dx.doi.org/10.1108/01409170110782865 
Adler, A. (1956). The individual psychology of Alfred Adler: A systematic presentation from selection of his writings. New York: Basic Books.

Alevesson, M. (1993). Organizations as rhetoric: Knowledge intensive firms and the struggle with ambiguity. Journal of Management Studies, 30(6), 997-1015. http://dx.doi.org/10.1111/j.1467-486.1993.tb00476.x

Ali, A. J. (2005). Islamic perspective on management and organization. Cheltenham: Edward Elgar.

Anderson, C. R., \& Schneier, C. E. (1978). Locus of control, leader behaviour and leader performance among management students. Academy of Management Journal, 21(4), 690-698. http://dx.doi.org/10.2307/255709

Andrews, F. M., \& Withey, S. B. (1976). Social indicators of well-being. New York: Plenum Press. http://dx.doi.org/10.1007/978-1-4684-2253-5

Andrisani, P. J., \& Nestel, G. (1976). Internal-external control as contributor to and outcome of work experience. Journal of Applied Psychology, 61(2), 156-165. http://dx.doi.org/10.1037/0021-9010.61.2.156

April, K., \& Smit, E. (2010). Diverse discretionary effort in workplace networks: Serving self over community in China. In Syed, J., \& Özbilgin, M. F. (Eds.), Managing cultural diversity in Asia: A research companion (pp. 73-109). Cheltenham: Edward Elgar Press.

Ashkanasy, N. M. (1985). Rotter's internal-external scale: Confirmatory factor analysis. Journal of Personality and Social Psychology, 48(55), 1328-1341. http://dx.doi.org/10.1037/0022-3514.48.5.1328

Bandura, A. (1973). Aggression: A social learning analysis. Englewood Cliffs, NJ: Prentice-Hall.

Bandura, A. (1977). Social learning theory. Englewood Cliffs, NJ: Prentice-Hall.

Bandura, A. (1994). Self-efficacy. In V. S. Ramachaudran (Ed.), Encyclopaedia of human behaviour (pp. 71-81). New York: Academic Press.

Benedict, P. (2007). In hope we were saved. Nairobi: Paulines Publications Africa.

Boone, C., \& De Brabander, B. (1997). Self-reports and CEO locus of control research: A note. Organisational Studies, 18(6), 949-1023. http://dx.doi.org/10.1177/017084069701800603

Boone, C., van Olffen, W., \& van Witteloostuijn, A. (2005). Team locus of control composition and leadership structure information and acquisition, and financial performance: A business study simulation. Academy of Management Journal, 48(5), 889-909. http://dx.doi.org/10.5465/AMJ.2005.18803929

Bovey, W. H., \& Hede, A. (2001). Resistance to organisational change: The role of defence mechanisms. Journal of Managerial Psychology, 16(7), 534-548. http://dx.doi.org/10.1108/EUM0000000006166

Bstan-'Dzin-Rgya-Mtsho, \& Cutler, H. C. (1998). The art of happiness: A handbook for living. New York: Riverhead Books.

Carney, S. (2007). Preserving/delaying gratification: Helping kids learn patience. [Online] Available: http://youthdevelopment.suite101.com/article.cfm/perseveringdelaying_gratification (November 30, 2010).

Carrim, N. M. H., Basson, J., \& Coetzee, M. (2006). The relationship between job satisfaction and locus of control in a South African call centre environment. South African Journal of Labour Relations, 30(2), 66-81.

Chung Y. Y., \& Ding, C. G. (2002). Development of the scales locus of control scale. Journal of Occupational Organisational Psychology, 75(2), 233-245. http://dx.doi.org/10.1348/09631790260098514

Cohen, S., Rothbart, M., \& Phills, S. (1976). Locus of control and the generality of learned helplessness in humans. Journal of Personality and Social Psychology, 34(3), 1049-1056. http://dx.doi.org/10.1037/0022-3514. 34.6.1049

Connolly, S. G. (1980). Changing expectancies: A counselling model based on locus of control. The Personnel and Guidance Journal, 59(3), 176-180. http://dx.doi.org/10.1002/j.2164-4918.1980.tb00525.x

Costa, P., \& McCrae, R. R. (1980). Influence of extraversion and neuroticism on subjective well-being: Happy and unhappy people. Journal of Personality and Social Psychology, 38(4), 668-678. http://dx.doi.org/10.1037/00 22-3514.38.4.668

Cummings, S., \& Wilson, D. C. (2003). Images of strategy. Oxford: Blackwell.

Darwin, C. (1936). The origin of species by means of natural selection. London: John Murray.

Davidson, R. J. (1998). Affective style and affective disorders: Perspectives from affective neuroscience. Cognition and Emotion, 12(3), 307-330. http://dx.doi.org/10.1080/026999398379628 
Diener, E. (1984). Subjective well-being. Psychological Bulletin, 95(3), 542-575. http://dx.doi.org/10.1037/003 3-2909.95.3.542

Diener, E., Emmons, R. A., Larsen, R. J., \& Griffin, S. (1985). The satisfaction with life scale. Journal of Personality Assessment, 49(1), 71-75. http://dx.doi.org/10.1207/s15327752jpa4901_13

Ganellen, R. J., \& Blaney, S. (1984). Hardiness and social support as moderators of the effects of stress. Journal of Personality and Social Psychology, 47(1), 156-163. http://dx.doi.org/10.1037/0022-3514.47.1.156

Grobler, P. A., Warnich, S., Carrell, M. R., Elbert, N. F., \& Hatfield, R. D. (2006). Human resource management in South Africa. London: Thomson Learning.

Gupchup, G. V., \& Wolfgang, A. P. (1997). A modified work of locus of control scale: Preliminary investigation or reliability and validity in a sample of pharmacists. Psychological Reports, 81(2), 640-642. http://dx.doi.org/10. 2466/pr0.1997.81.2.640

Haidt, J. (2006). The happiness hypothesis: Finding modern truth in ancient wisdom. New York: Basic Books.

Hawa, S. (2004). Tarbeitena alruhiya. Cairo: Dar-Alsalam.

Headey, D., \& Wearing, A. (1992). Understanding happiness: A theory of subjective well-being. Melbourne: Longman Cheshire.

Hiers, J. M., \& Heckel, R. V. (1977). Seating choice, leadership and locus of control. Journal of Social Psychology, 103(2), 313-14. http://dx.doi.org/10.1080/00224545.1977.9713334

Hiroto, D. S. (1974). Locus of control and learned helplessness. Journal of Experimental Psychology, 102(2), 187-193. http://dx.doi.org/10.1037/h0035910

Holder, E. E., \& Levi, D. J. (1988). Mental health and locus of control: SCL-90-R and Levenson's IPC scales. Journal of Clinical Psychology, 44(5), 753-755. http://dx.doi.org/10.1002/10974679(198809)44:5<753::AID-JC LP2270440514>3.0.CO;2-A

Hyatt, T. A., \& Prawitt, D. F. (2001). Does congruence between audit structure and auditor's locus of control affect job performance? The Accounting Review, 76(2), 263-274. http://dx.doi.org/10.2308/accr.2001.76.2.263

Joe, V. C., \& Jahn, J. C. (1973). Factor structure of the Rotter IE Scale. Journal of Clinical Psychology, 29(1), 66-68. http://dx.doi.org/10.1002/1097-4679(197301)29:1<66::AID-JCLP2270290125>3.0.CO;2-G

Kamil, N. M., Al-Kahtani, A. H., \& Sulaiman, M. (2011). The components of spirituality in the business organizational context: The case of Malaysia. Asian Journal of Business and Management Sciences, 1(2), 166-180.

Kelly, G. (1955). The psychology of personal constructs. New York: Norton.

Klein, J., \& Wasserstein-Warnet, M. (1999). Predictive validity of the locus of control test in selection of school administrators. Journal of Educational Administration, 38(1), 7-24. http://dx.doi.org/10.1108/09578230010310 957

Klockars, A. J., \& Varnum, S. W. (1975). A test for the dimensionality assumptions of Rotter's internal-external scale. Journal of Personality Assessment, 39(4), 39. http://dx.doi.org/10.1207/s15327752jpa3904_13

Knowles, M. S., Holton, E. F., \& Swanson, R. A. (1998). The adult learner: The definitive classic in adult education and human resource development. Houston: Gulf Pub. Co.

Kobler, A. L., \& Scotland, E. (1964). The end of hope: A social-clinical study of suicide. New York: Free Press of Glencoe.

Landy, F. J., \& Conte, J. M. (2004). Work in the 21st century: An introduction to industrial \& organizational psychology. Boston, MA: McGraw-Hill.

Leedy, P. D., \& Ormrod, J. E. (2005). Practical research: planning and design. Upper Saddle River: Pearson Merrill Prentice Hall.

Lee-Kelley, L. (2006). Locus of control and attitudes to working in virtual teams. International Journal of Project Management, 24(3), 234-243. http://dx.doi.org/10.1016/j.ijproman.2006.01.003

Lefcourt, H. M. (1976). Locus of control. New York: Lawrence Erlbaum Associates.

Levenson, H. (1973). Multidimensional locus of control in psychiatric patients. Journal of Consulting and Clinical Psychology, 41(3), 397-404. http://dx.doi.org/10.1037/h0035357 
Littunen, H., \& Storhammar, E. (2000). The indicators of locus of control in the small business context. Journal of Enterprise Culture, 8(4), 343-360. http://dx.doi.org/10.1142/S0218495800000188

Lyubomirsky, S., Sheldon, K. M., \& Schkade, D. (2005). Pursuing happiness: The architecture of sustainable change. Review of General Psychology, 9, 111-131. http://dx.doi.org/10.1037/1089-2680.9.2.111

Marks, L. I. (1998). Deconstructing locus of control: Implications for practitioners. Journal of Counselling and Development, 76(3), 251-259. http://dx.doi.org/10.1002/j.1556-6676.1998.tb02540.x

Martin, R., Thomas, G., Charles, C., Epitropaki, O., \& McNamara, R. (2005). The role of leader-member exchanges in mediating the relationship between locus of control \& work reactions. Journal of Organisational \& Occupational Psychology, 78, 141-147. http://dx.doi.org/10.1348/096317904X23763

McCullough, P. M., Ashbridge, D., \& Pegg, R. (1994). The effect of self-esteem, family structure, locus of control, and career goals on adolescent leadership behavior. Adolescence, 29(115), 605-611.

McPeck, C. (2007). The causes of internet and TV addiction. [Online] Available: http://www.causeof.org/endor phins.htm (March 4, 2011).

Mindell, A. (2007). Edges of experience: Jung, process work and collective change. [Online] Available: http://www.aamindell.net/1263/processwork-theory-applications/processwork-history/cg-jung-and-process-work / (February 9, 2012).

Minkoff, K., Bergman, E., Beck, A. T., \& Beck, R. (1973). Hopelessness, depression, and attempted suicide. The American Journal of Psychiatry, 130(2), 455-459.

Pavot, W., \& Diener, E. (1993). Review of the satisfaction with life scale. Psychological Assessment, 5(2), 164-172. http://dx.doi.org/10.1037/1040-3590.5.2.164

Peterson, C., Maier, S. F., \& Seligman, M. E. P. (1993). Learned helplessness. New York: Oxford University

Press.Reynaert, C., Janne, P., Vause, M., Zdanowicz, N., \& Lejeune, D. (1995). Clinical trials of antidepressants: Where locus of control appears to play a key role in depression outcome. Psychopharmacology, 119(4), 449-454. http://dx.doi.org/10.1007/BF02245861

Ricard, M. (2006). Happiness: A guide to developing life's most important skill. New York: Little Brown.

Rotter, J. B. (1966). Generalized expectancies for internal versus external control of reinforcement. Psychological Monographs: General and Applied, 80(1), 1-28. http://dx.doi.org/10.1037/h0092976

Rotter, J. B., Seeman, M., \& Liverant, S. (1962). Internal versus external control of reinforcement: A major variable in behaviour theory. In N. F. Washburne (Ed.), Decisions, values and groups (Vol. 2). London: Pergamon Press.

Sandvik, E., Diener, E., \& Seidlitz, L. (1993). Subjective well-being: The convergence and stability of self-report and non-self-report measures. Journal of Personality, 61(3), 317-342. http://dx.doi.org/10.1111/j.146 7-6494.1993.tb00283.x

Saunders, M., Lewis, P., \& Thornhill, A. (2003). Research methods for business students (3rd ed.). Harlow: Pearson Education Limited.

Shapiro, D. H., Schwartz, C. E., \& Austin, J. A. (1996). Controlling ourselves, controlling our world. American Psychologist, 51(12), 1213-1230. http://dx.doi.org/10.1037/0003-066X.51.12.1

Skinner, B. F. (1974). About behaviourism. New York: Knopf.

Spector, P. E. (1988). Development of the work locus of control scale. Journal of Occupational Psychology, 61(4), 335-340. http://dx.doi.org/10.1111/j.2044-8325.1988.tb00470.x

Suh, E., Diener, E., Oishi, S., \& Triandis, H. C. (1998). The shifting basis of life satisfaction judgments across cultures: Emotions versus norms. Journal of Personality and Social Psychology, 74(2), 482-493. http://dx.doi.org/10.1037/0022-3514.74.2.482

Timmons, J. A., Spinelli, S., \& Zacharakis, A. (2005). How to raise capital techniques and strategies for financing and valuing your small business. New York: McGraw-Hill.

Torun, E., \& April, K. (2006). Rethinking individual control: Implications for business managers. Journal for Convergence, 7(1), 36-39.

Tyler, B., Gatz, M., \& Keenan, G. (1979). A constructivist analysis of the Rotter I-E scale. Journal of Personality, 47(1), 11-35. http://dx.doi.org/10.1111/j.1467-6494.1979.tb00612.x 
Utts, J. M., \& Heckard, R. F. (2007). Mind on statistics. Belmont, CA: Duxbury, Thomson Brooks/Cole.

Van Dyk, P. S., Nel, P. S., Van Zloedolff, P., \& Haasbroek, G. D. (2001). Training management: A multidisciplinary approach to human resources development in Southern Africa. Oxford: Oxford University Press.

Veenhoven, R. (1991). Is happiness relative? Social Indicators Research, 24(1), 1-34. http://dx.doi.org/10.1007/ BF00292648

Wilson, J. P. (1999). Human resource development: Learning and training for individuals and organizations. London: Kogan Page.

Wong, P. T. P., \& Sproule, C. F. (1984). An attributional analysis of the locus of control construct and the Trent Attribution Profile. In H. M. Lefcourt (Ed.), Research with the locus of control construct (Vol. 3) (pp. 309-360). New York: Academic Press.

Individuals with an internal locus of control believe that events result primarily from their own behaviour and resources (Rotter, 1966)
Those with an external locus of control believe that forces out of their control, such as powerful others, fate, or chance, primarily determine events (Rotter, 1966)

\section{External Locus of control}

A bi-local expectancy exists where in certain aspects of life an individual will attribute reinforcements to external factors while in other functions, he or she will attribute reinforcements to internal factors. The mechanism by which these expectancies co-exist is not fully understood

(Connolly, 1980)

Figure 1. Rotter's (1966) concept of locus of control illustrated as a dimension with two opposing differentiates

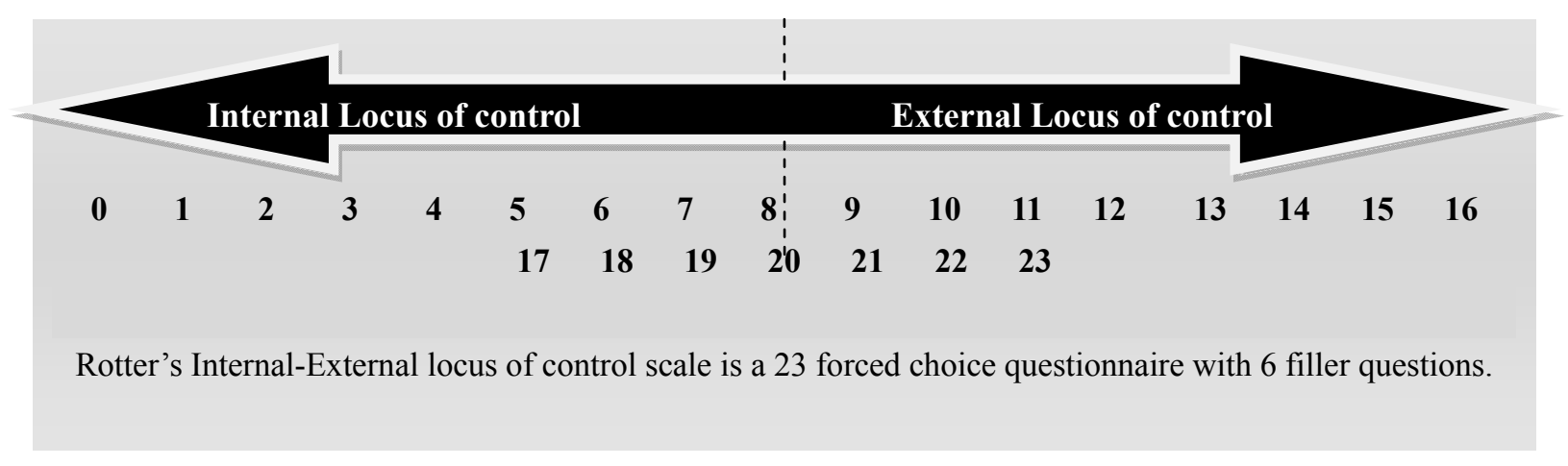

Figure 2. Rotter's (1966) internal-external scale scores 

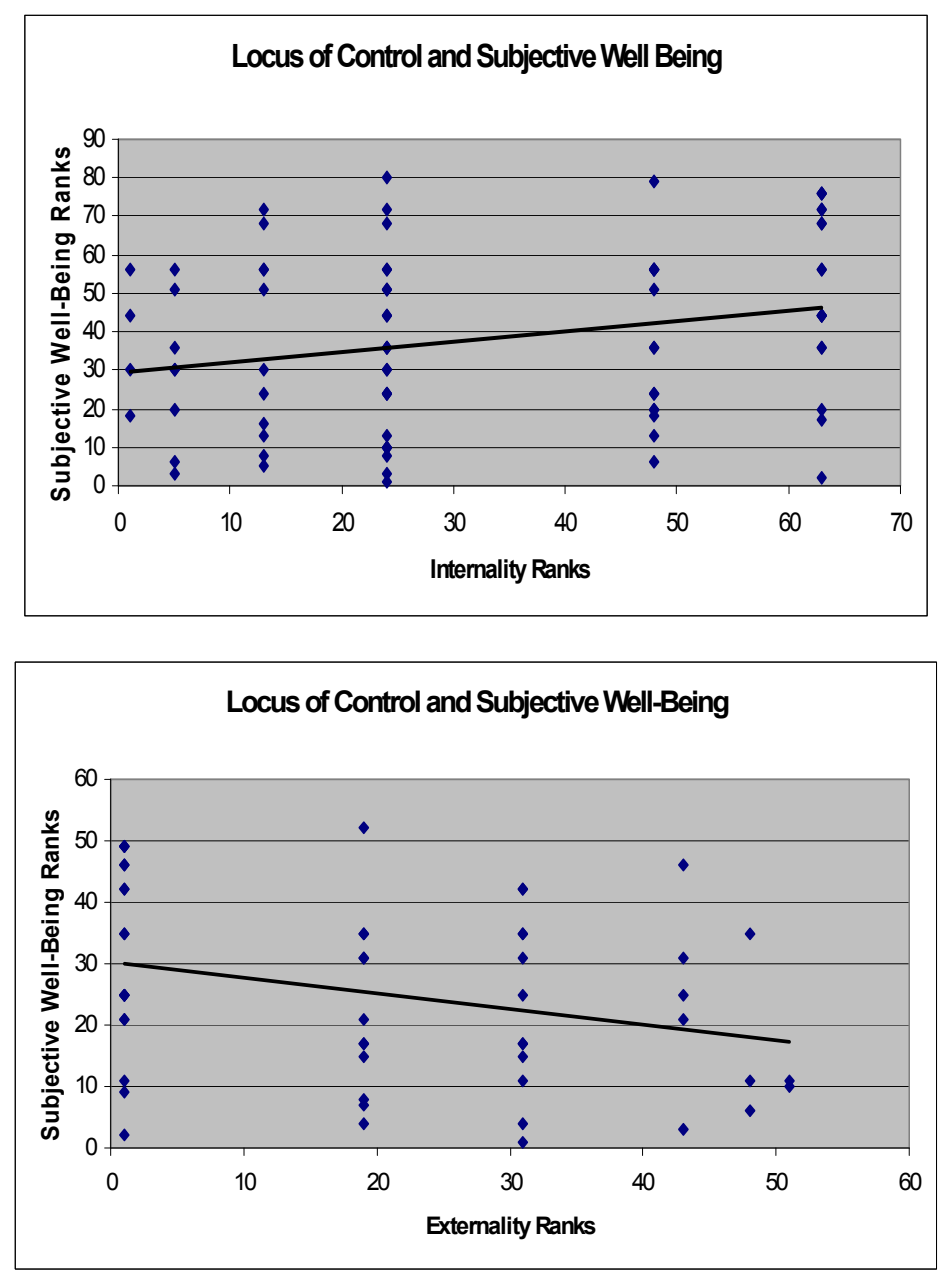

Figure 3. Two separate tests results of Locus of control (Internal \& External) and its impact on subjective well-being depicted graphically

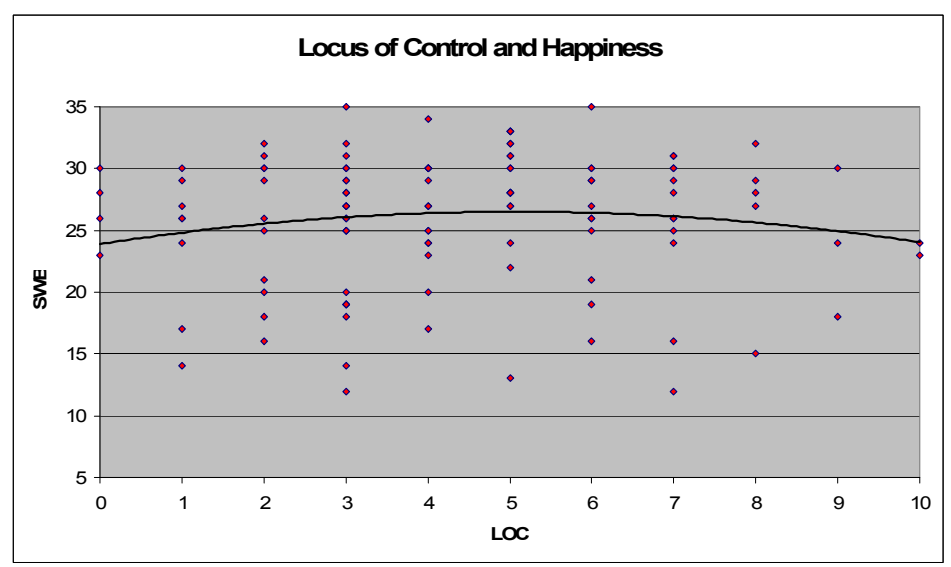

Figure 4. Maximum level of happiness achieved by individuals with a bi-local expectancy

Table 1. Correlation coefficients and level of significance

\begin{tabular}{llll}
\hline Locus of control vs. subjective well-being & Sample size $-\mathrm{n}$ & Correlation coefficient & Level of significance \\
\hline Internality & 80 & 0.309 & $1 \%$ \\
Externality & 52 & -0.470 & $1 \%$ \\
\hline
\end{tabular}

